\title{
Proposal studies of using eco-protection for the highway embankment side slope erosion in Sudan by applying native vegetation
}

\begin{abstract}
The uses of plants for soil erosion protection and slope stabilization has a long tradition, old methods with rocks and plants, structures of timber have been used over the past centuries. Recently these old soil conservation and stabilization techniques have been rediscovered and improved. Eco-protection Technology methods have become part of highway engineering and construction and have helped bridge the gap between classical engineering disciplines, land use management, landscape architecture and biological sciences. In this review, the study searching the possibility of using vegetation to protect the side slopes of embankment by proposing using different types of vegetation for protesting the erosion of this road in the Sudan is presented. The core of this review is a comprehensive overview of the most important of Eco-protection technology methods it can be used for slope soil erosion protection and slope stabilization. Geotechnical experiments, descriptions of soil experiments, procedures, and the major advantages of using existing grass and plants as local vegetation in eco-protection of the national road slope, and review of using vegetation as the Biotechnical method is discussed which based on the study results. Considerations about the importance of Eco-protection and stabilizes the National Road slope soil in this review.
\end{abstract}

Keywords: slope erosion, ecological protection, bio-technical techniques, rainfall intensity, geotechnical properties, soil fertility, existing vegetation, cynodon dactylon, mesquite, vetiver
Volume I Issue 2 - 2017

\author{
Altaeb Mohammed, Xu Wennian, Xia \\ Zhenyao, Dig Yu \\ College of Civil Engineering \& Architecture, China Three Gorges \\ University, China
}

\begin{abstract}
Correspondence: Xu Wennian, College of Civil Engineering \& Architecture, China Three Gorges University, Yichang, Hubei 443002, China, Email altayebnona@gmail.com
\end{abstract} Received: September 09, 2017 | Published: September 15,
2017

\section{Introduction}

Road construction has increased significantly worldwide in the last decades to meet the demands of the increasing human population, ${ }^{1}$ and rainfall intensity affecting the highway embankment side slope erosion, and this has led to thinking about using the serious protection methods to solve soil erosion problems. Highway slope erosion causes some traffic accident, and there were unaccounted for, especially in the developing world as in the Sudan (National Road) the area of the research study. The failure of the embankment of soil slopes along the national Road is a serious problem. ${ }^{2}$ And according to the head of traffic police in Gezira state, he said during the autumn season there increasing in the rainfall intensity, which caused dangerous vehicular traffic on this kind of roads, and that due to the presence of side slope. And he stressed the seriousness of stopping vehicles from making parking or stop on the side shoulders of the road; this due to the eroded slope soil by the rainfall intensity and this caused many accidents. He mentioned the annual victims of traffic accidents in this street about 15-25 person. Generally, slope protection is one of the important civil engineering activities. Especially for highways, which constructed on a mountain or height embankment slopes.

Erosion of soil slopes can undermine pavements and other structures, create safety hazards, and harm the environment. Repair of eroded soil slopes can be problematic because of difficult access and working conditions. Such difficulties can result in high costs for slope repair. Effective erosion protection measures can prevent or reduce the scope of such problems ${ }^{2}$ and the advantages of highway slope Ecological Protection (Bio-technical techniques of Slope Protection) are: creating a good environment surrounding the road area, improving the climate situation and adding a beautiful landscape view. In addition to the main purpose is protecting the soil slope from sliding or erosion, which caused by the natural factors as rainfall or the wind. ${ }^{3}$ Using the modern Eco-protection Technology as in western world experiences, and nowadays in China the Eco-Protection technology for highway slope protection, it's rapidly develop, and the study is trying to bring and adopt these technologies in Sudan, the study expects to find a perfect method of slope erosion protection as solution in Sudan highway slope. And this will be after studying the climate, the existing vegetation, the rainfall intensity and the soil classification and fertility also.

\section{Background of study}

Usually, Sudan has not this kind of steep slopes as in western countries as USA, Japan or in China, and that because of flat lands and it has not many hills or mountain roads. So they cut back slopes of the highway cannot find in Sudan, but there are some roads constructed on high embankment fill in the lowland areas, to protect erosion caused by water flow which coming from rainfall during the autumn season. An addition to the maximum rainfall intensity reaches the highest degree during the autumn season, and the heights of road slope embankment between 2.5 to $3.5 \mathrm{~m}$, then this study is trying to use Ecological Protection to prevent the highway side embankment slope in some roadway in Sudan as in China for protecting (The national road) in Gezira State in Sudan, this road linked most of the other states with the capital of Sudan Khartoum, because it's national road. According to some engineering, surveying, and measures, about the situation of the road showing the embankment side slope clear eroded by rainfall intensity. 
Even the police traffic department and ministry of the infrastructure department of highway and bridge records prove that most of the traffic accidents occurred on this road during the autumn season, as results of rain water flow, which causes erosion in the road embankment side slopes. The research study the highway embankment slope situation in Sudan and determine the best method for protecting the roadside slope to reduce the amount of traffic accident during the autumn season in the Gezira state (National road) which caused by soil erosion due to rainfall intensity. Identify and use the new technology of Eco-protection to prevent road slope in Sudan, depending on the Eco-protection Technology concepts.

\section{Aims of research}

The expected aims to lead to stabilize the soil slope as follows:

a. Study the embankment slope roads (by making engineering measuring).

b. Determining suitable method for protecting slope against failure and control slope erosion.

c. Trying to adopting ecological protection methods in roadway constructional industries in the Sudan in the future.

d. Adding roadway slope Eco-protection as a part of highway specifications construction.

This study is considered as efficient planning for erosion control requires a comprehensive consideration of site topography, drainage pattern, rainfall data, soil data, existing vegetation, as well as available types and operational characteristics of the erosion control methods. These varied and complex considerations, commonly limit the number of problems encountered in finding feasible and economic methods to minimize erosion. Several disciplines of science and engineering are required to address erosion problems. Highway designers, project engineers, and maintenance personnel often need the advice of hydrologists, hydraulic engineers, soil engineers, soil scientists, agronomists, landscape architects, and other specialists minimize erosion problems. ${ }^{2}$

\section{Description of study area}

\section{Location and topography}

The Road, located in the middle of Sudan in the Gezira State. It has length 45K.M. And linking between the capital of the Gezira state (Wad Medani) city and the (Sennar) city the capital of Sennar State near the Sennar Dam. This road is a part of the national roadway. There is a big agricultural scheme called Gezira Scheme. ${ }^{4}$ The Gezira state located at Blue Nile Region, the area $27,549 \mathrm{~km}^{2}$ means 10.637 miles, population 2,796,330. This road is used to carry passengers, coups and products between two cities and also it continues to the north until reaching Khartoum capital of Sudan. The importance of the study to find out a suitable method to protect the embankment slope erosion. And by that reduce traffic accidents, there are many dangers in using the part of the National road during the autumn season. The rainfall intensity during autumn is affected on the side slope of the road embankment materials making soil erosion. And this is showing the importance of this study. The side slope height is 1.05-3.5meters. In this study, we choose the longitudinal section $650 \mathrm{~m}$ as the most dangerous part of the street.

\section{Gezira scheme}

Gezira state has a bigger agricultural scheme called (Gezira Scheme) is one of the largest irrigation projects in the Africa, just southeast of the confluence of the Blue Nile River at the city of Khartoum the capital of Sudan. ${ }^{4}$ The Gezira Scheme was begun by the British while area governed as the part of Anglo-Egyptian Sudan. Water from the Blue Nile distributes through canals and ditches to tenant farms lying between the Blue Nile and White Nile rivers. The main crop is Cotton (Figure 1).

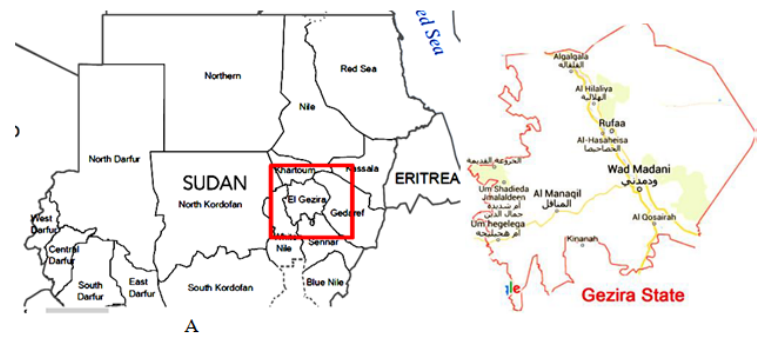

Figure I Republic of Sudan and Gezira State.

\section{Topography}

Most of the Gezira State surface is flat plains there is no a lot of mountains or hills. And most it areas lay in mudflats in the middle of Sudan, and there the Nile River along the state running from south to the north of the state.

\section{Climatic conditions}

Sudan has a tropical continental climate over most of the country. The climate ranges from a desert climate in the north having a short, unreliable rainy season during the months of July-September, to an equatorial rainy zone in the south having a short dry season in the months of December-January. ${ }^{5}$ Gezira state has a dry climate, which is characterized by seasonal rain during the (July to September) months, and the rainfall intensity increased in the south of the state.

\section{The rainfall seasons and rain intensity in gezira}

According to the Meteorological Authority annually in Gezira State, the average of rainfall intensity is $350 \mathrm{~mm}$ and the humidity percentage is $180-70 \%$ and decreases during the dry season reach $32-18 \%$ the annual average high temperature is $36.5^{\circ}$ and the annual average minimum temperature is $20.6^{\circ} .{ }^{6}$ Rainfall commenced earlier this season in the southern part of Sudan, with high amounts across the western states during May, associated with below average rainfall and drier conditions in most parts of central and eastern states. Consistence rainfall started in June in most parts of the country with good rainfall amounts. Rainfall reached the northern part of Sudan as a consequence of the northward movement of the humid air masses During May and early June. Suitable early planting conditions were favourable during late May and early June in the southern areas ${ }^{5}$ (Figure 2).

\section{Geotechnical properties}

They most types of Al Gezira soil are alkaline - clay soil as in (Figure 3), and for studying the slope, soil Geotechnical properties, they are many experiments conducted as: 
a. Moisture content to calculate MC of soil.

b. Soil density to determine dry density $\left({ }^{\gamma} \mathrm{d}\right)$ of the site by using sand cone method.

c. The fertility of the soil by calculating the nitrites values as $(\mathrm{N}, \mathrm{P}$, $\mathrm{K}, \mathrm{OM}$, and $\mathrm{pH})$.

A soil fertility test evaluates the nutrient-supplying power of a soil. The results of the test are used to predict if, or how much fertilizer is required for optimum plant growth. Soil tests as civil engineering requirement. Some soil tests were done on the site and in laboratories, the (Soil Density) done on site using the method of replacing and cone on the compacted gravel layers in road shoulders. Soil samples were taken to the Wad Medani Technological College (WMTC) laboratories to test the (Moisture Content) of the site soil. Also, the samples of road base and sub-base (Upper Gravel layers) to check these two layers graduation (Sieves Analysis) for the road. ${ }^{7}$ All experiments have been done in Wad Medani Technological College (WMTC) in Civil Engineering Department laboratories and in Gezira University College of Agricultural Science laboratories. In the suite test of road is the soil field density, done by using (sand replacement method) according to the American Society for Testing Materials (ASTM 1992ao). ${ }^{8}$ Sieve analysis for determining the graduation of upper layers (gravel layers base and sub-base) of road pavements. (Figure 4) The sieve analysis did because to ensure the homogeneity of gravel materials and to know the situation of the upper pavement compaction of the road.

Figure 5 presents a generalized soils map of Sudan showing the several soil types which have developed because of differences in climate, the nature of the parent rock, relief, drainage and vegetation. ${ }^{5}$ Desert sands occur in the north and west of Sudan, immature semidesert soils in the low mountain range along the Red Sea, alkaline soils along the Ethiopian border, and reached, lateritic soils in the far south and southwest areas. In addition, alluvial soils occur along the White Nile (between Khartoum and Malakal), the Blue Nile (between Khartoum and Rose rec), the main Nile (north of Khartoum), and along portions of other rivers. The area consisting of alkaline clay soils is termed the Clay Plain. The northern Clay Plain soils, locally termed Black Cotton soils, are generally weathered sediment derived from the volcanic Ethiopian Highlands. The soils are commonly alkaline, containing calcium carbonate and gypsum, with the Clay fraction composed largely of montmorillonite. The southern Clay Plain soils are thought to be residual soils and are similar to the northern Clay Plain soils but without gypsum.

\section{Data about soil chemical components of soil fertility}

Collected data the chemical components (Nutrients tests) for determining soil fertility of the site, also it's a helpful to know the types of grass family and plants to use in future to slope ecological protection in the high embankment side slope of the road as Eco-Protection method. This chemical soil test did in the Gezira University-college of agricultural sciences and water resources. From collaborating with teachers from Gezira University we discussed the possibilities of using vegetation (plants and grass family) according to soil fertility, knowing the existing natural plant grasses in the site, determining the suitable Poaceae as Cynodon dactylon is also known as Vifastella (Chippindall, 1976). The study collaborated with other professors' belonged to different colleges, and department to make a merge and sharing information, and they are participating in success this study. Prof. Adam is the one who is working on a chemical analysis of soil in most areas in Sudan and especially in Gezira state. He provides the studies with the data about the fertility of the soil in the area of Road (Table 1). Comparing above data, of soil elements with previous studies done by Dr. Muawia El Bedawi Hamad, we found those elements of fertility are acceptable (Figure 6). His study was located in the four areas in the Gezira state (Al Hosh, Darwish, Suleiman, and Kab elgidad $),{ }^{8}$ and the characteristics of the soil shown below (Table 2):
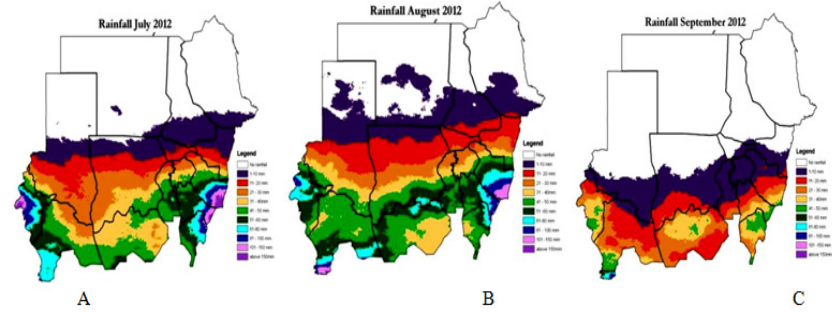

Figure 2 Monthly Rainfall amounts in June, July, August, and September.
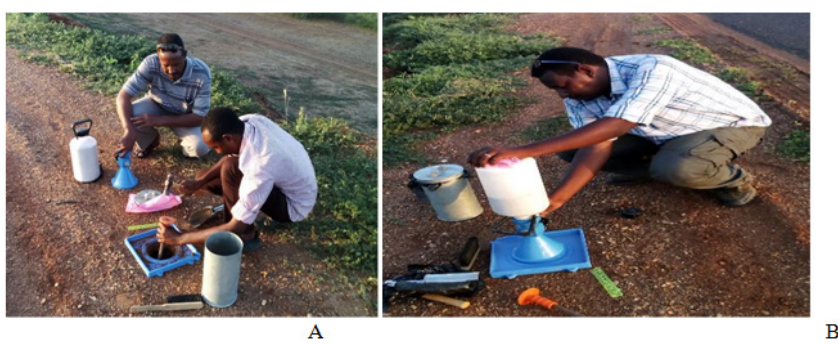

Figure 3 Preparing and Doing for Field Density Test.
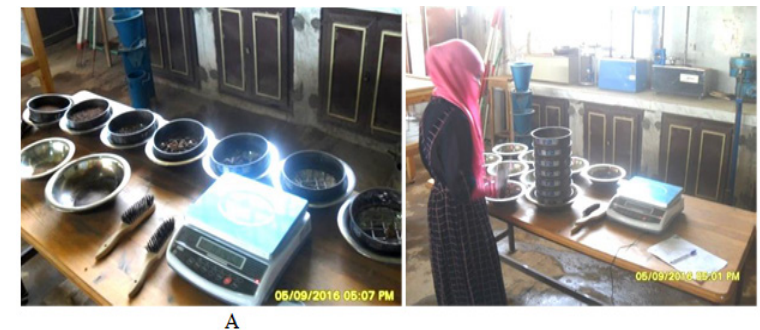

Figure 4 Soil Laboratory in WMTC.

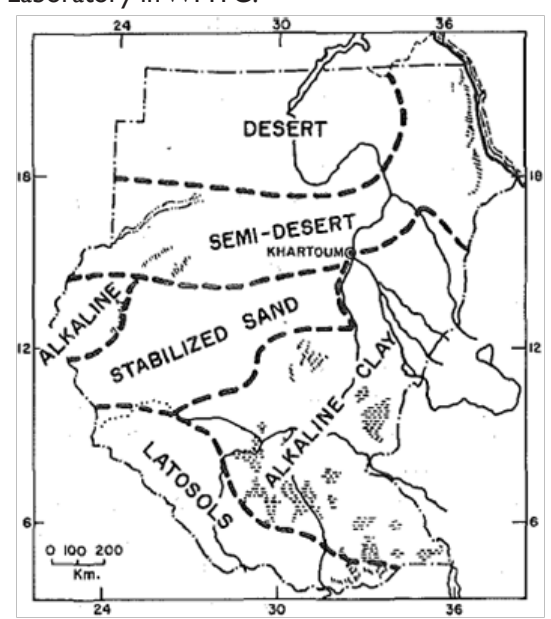

Figure 5 Monthly Rainfall amounts in June, July, August, and September. 


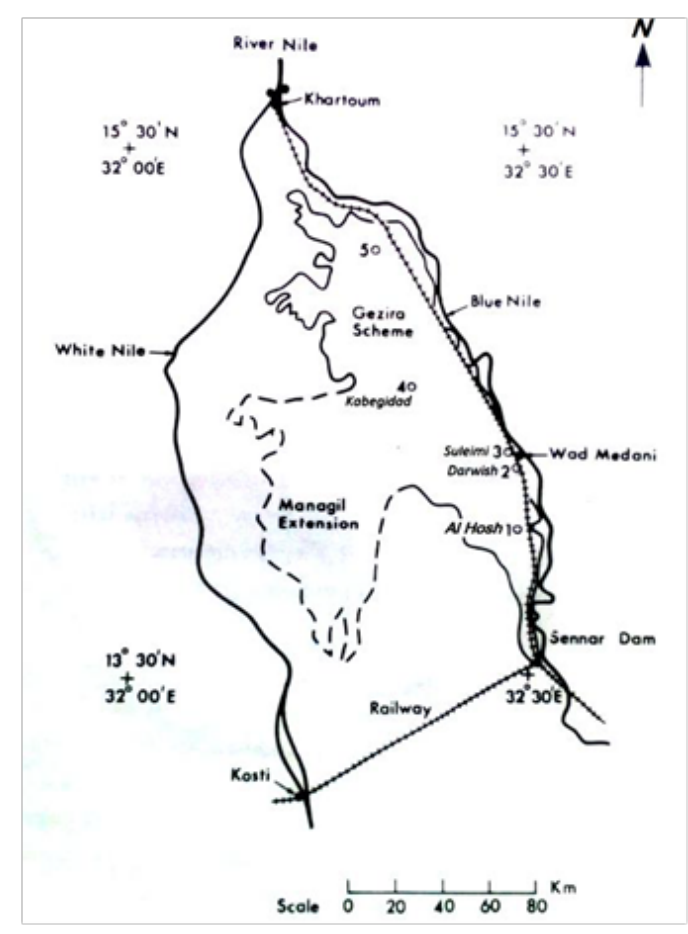

Figure 6 Map of Gezira Scheme showing location of tests.

Table I Elements of Soil Fertility (Prof.Adam)

\begin{tabular}{ll}
\hline Elements & Value \\
\hline $\mathrm{N}$ & $0.03-0.45 \%$ \\
$\mathrm{P}$ & $2-4 \mathrm{ppm}$ \\
$\mathrm{K}$ & $0.5-0.6 \mathrm{me} / 100 \mathrm{~g}$ \\
$\mathrm{OM}$ & $0.4-0.5$, less than $1 \%$ \\
$\mathrm{pH}$ & $7.5-8.5$ \\
\hline
\end{tabular}

Table 2 Elements of Soil Fertility (Prof. Muawia)

\begin{tabular}{ll}
\hline Elements & Value \\
\hline $\mathrm{N}$ & $0.73 \%$ \\
$\mathrm{P}$ & $2-4 \mathrm{ppm}$ \\
$\mathrm{K}$ & $0.95 \mathrm{me} / 100 \mathrm{~g}$ \\
$\mathrm{OM}$ & 0.5, less than $1 \%$ \\
$\mathrm{pH}$ & 8.44 \\
\hline
\end{tabular}

The main agents for the slope failure along the national road

Generally road construction creates numerous road cut and fill embankments, as well as ditch or culvert sites that contribute to runoff and high sediment production that cause extreme land degradation. ${ }^{9}$ Road cut and fill embankments have bare and steep gradients that cause the generation of runoff and sediment yield. ${ }^{10}$ Lack of vegetation cover also intensifies soil detachment by raindrops and proliferates susceptibility to erosion as a result of reduced cohesion and shear strength of the soil. ${ }^{11}$ The effect of water on the slope can be considered into two fold. One is ground water or aquifer below the surface that generates pore water pressure and the other is rainwater infiltration that seeps through the surface and flows along the slope generating water pressure. It is related to the surrounding precipitation levels, topography, nearby water masses, and the Geo-hydrological characteristics of the rock mass. According to the surveying and engineering measuring there were important agents has to pay basic role of the failure along the national slope.

The cause of the road slope failure due to the following main factors:

Erosion caused by rainfall intensity, as mentioned before on location and topography part, the rainfall intensity occurred side slope erosion along the national Road.

a. The soil of the upper gravel layers, is not well graded, according to the sieve analysis showed a gap graduation. And makes a poor soil compaction.

b. The road does not have side ditch to discharge surface water.

c. No any type of slope protection as slope Mechanical protection.

\section{Mitigating the problem by using ecological protection technology}

Constructed roads on high embankment it creates slop it need of vegetation cover to protect the erosion. Furthermore, there is a variety of erosion control measures for controlling road-related erosion. We are of the view that this study provides guidance on future research on road-related soil erosion. For the reducing the highway traffic accidents, one of these erosion control methods is a biotechnology of slope protection, using the vegetation cover to stabilize the slope. A Bio-Technical technique has many advantages improve aesthetic values, and usually, moderate to a large saving in cost. The plant roots can provide a great deal reinforcement to the unstable soil, prevent soil and greatly reduce surficial erosion. ${ }^{12}$ According to all information about site meteorological data, the site Geotechnical properties, the existing vegetation (Local vegetation) and chemical soil experiments, data so the study advice to apply slope Eco-protection.

\section{The work which has done}

Engineering measures of the eroded roadside slope and Surveying measures. The study measured the eroded area on the road slope by surveying measures, the effective slope area, and the length of most eroded $350 \mathrm{~m}$ as shown in (Figure 7) and the cross section in (Figure 8). Two cross section shows the height and the slope angles. This done after studying the nature of side and is mentioned before the climate and microclimate. And study and surveying measures of national road side slope as in (Figure 9) showed how the degree of the eroded soil. During the autumn season the shoulders of the road are very dangerous, and there are no side ditch channels to discharges the surface water coming from rainfall. And these cause the side slope erosion for the road (Figure 10).

According to the experiments works, engineering and surveying measures, the study suggested using some existing plants and grass which grow near the road slope. The soil tests results and collected data shows the ability to use vegetation the slope surface to control the erosion caused by rainfall intensity during the autumn season. Below 
is stated of soil experiments and soil data supported by all tables and figures (Table 3) (Table 4). Present the experiment results which done at Wad Medani Technical College (WMTC) (Figure 11).

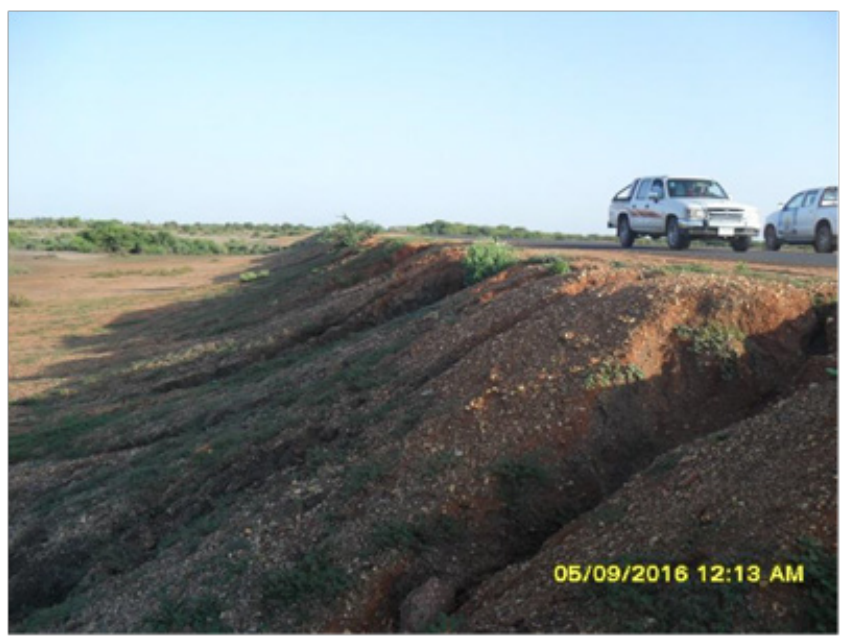

Figure 7 Picture shows the eroded side slopes of National Road.
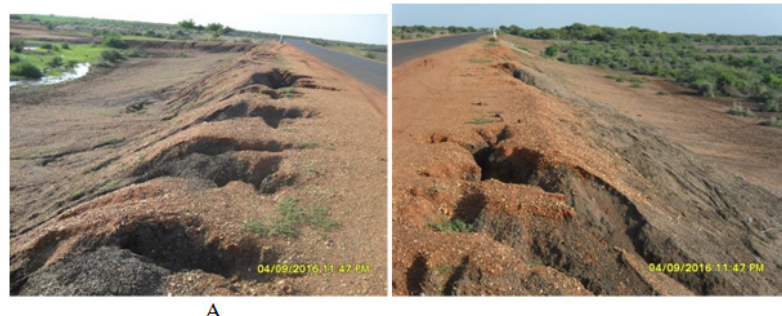

Figure 8 Pictures show the degree of eroded slope along National road.

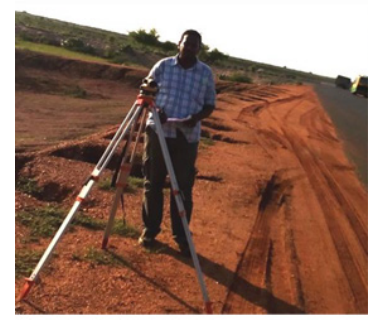

A

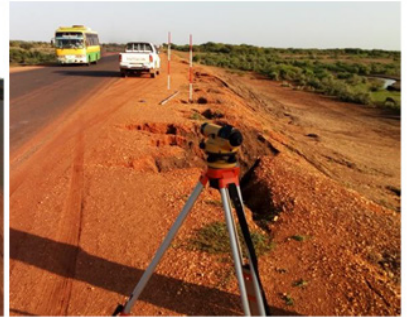

B

Figure 9 Surveying \& Engineering measures Studies showing the eroded section of the Road.

\section{Soil nutrients experiments}

The study tries to check the chemical and physical character data, for suite soil of the Road slope; the below tables show the data for nitrite tests, from the University of Gezira, at college of agricultural sciences, they have a data about the chemical elements of soil in the most Gezira state zones. The soil fertility of the road is important to success the vegetation slope cover. The chemical components of soil in the Road area as shown in the Table 5.

\section{Chemical test results (Soluble ions)}

Then we compare this data of Prof. Muawia El Bedawi with Prof.
Adam, Muawia has wide experiences in testing Gezira state soil and he made soil chemical test for four different areas in Gezira state included an area of Road, ${ }^{13}$ which were our road project. The soil chemical test results which done by Prof. Muawia near to the Prof. Adam results as shown in Tables 6 \& 7 .
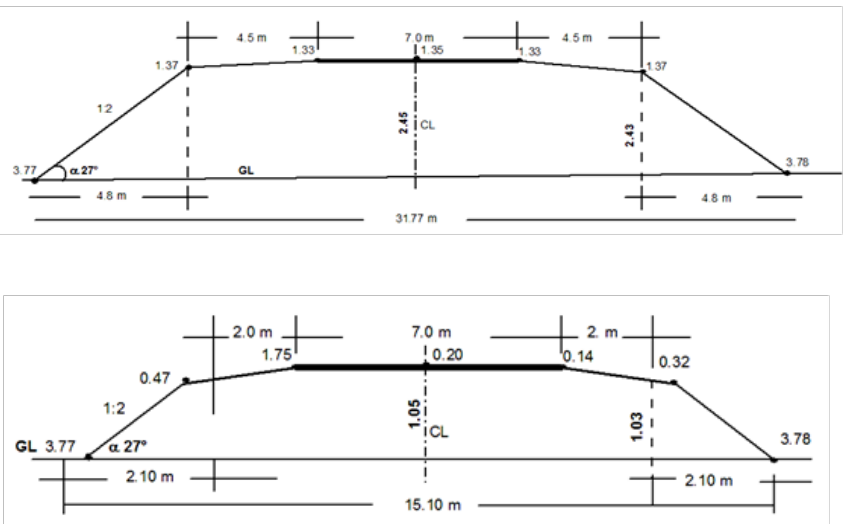

Figure 10 National Road tow cross- sections.

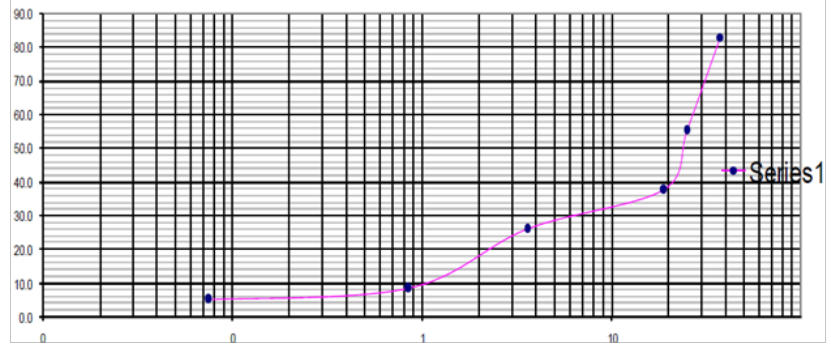

Sieves Opening (mm) \& Passing Diagram.

Figure I I Grain Size - Distribution.

Table 3 Determination of Moisture Content:WC=22.1\%

\begin{tabular}{llll}
\hline Number & Item cont. number & Cont. number W & $\begin{array}{l}\text { Test } \\
\text { weight } \\
\text { (Kg) }\end{array}$ \\
\hline 1 & Mass of empty con. & W1 & 0.07 \\
2 & Mass of con. + Wet Soil & W2 & 0.134 \\
3 & Mass of con. + Dry Soil & W3 & 0.122 \\
4 & Mass of moisture & W2 - W3 & 0.012 \\
6 & Mass of Dry Soil & W3 - W1 & 0.052 \\
\hline
\end{tabular}

The soil of National Embankment side slope

\section{Plant and community of grass}

After studying all above-mentioned situations about soil tests, data from meteorological authority, the chemical elements of soil, the sloping embankment of the Road, the information from traffic police about the dangers on this road and should make some protection save people life, it is important to study the feasibility of using the plant and grass in Sudan that can use it in the Eco -protection of the National embankment road. The proposed plant species (Cynodon Dactylon, local Cyperuses), the study prefers the planting time will be in autumn 
season because of the temperature, rainfall intensity to give a better vegetation result. The vegetation existing near the road which have vegetated naturally it's the best indicator of the part spectrum use. These plants are native (exotic), and the choice must be between the local plants or exotic species because local plants are often mandatory in regional. Native species have known adapting to the climate and soils of the project area. For bio- Geotechnical construction and striking unrooted cuttings, materials can often be found close by. ${ }^{4}$

Table 4 Sieve Analysis

\begin{tabular}{lllll}
\hline Sieve open size mm & Cum. WT retained & Cum. WT retained\% & Cum. WT retained\% & Cum. WT pass\% \\
\hline 37.5 & 340 & 17 & 17 & 83 \\
25 & 553.6 & 27.68 & 44.7 & 55.3 \\
19 & 351 & 17.55 & 62.2 & 37.8 \\
3.6 & 235.5 & 11.78 & 74.1 & 26 \\
0.83 & 15.13 & 89.1 & 8.5 \\
0.075 & 113.5 & 5.68 & 94.9 & 5.2 \\
PAN & 5 & 0.3 & & \\
\hline
\end{tabular}

Sieve Analysis*

Tested by, Harm Adam

*Oven Dry W=2000, Date 25.08.2016

Table 5 (Fertility elements)

\begin{tabular}{ll}
\hline Element & Amount \\
\hline $\mathrm{OM}$ & $0.4-05$ less than $1 \%$ \\
$\mathrm{~N}$ & $0.03-0.4 \%$ \\
$\mathrm{P}$ & $2-4 \mathrm{ppm}$ \\
$\mathrm{K}$ & $0.5-0.6 \mathrm{me} / 100 \mathrm{~g}$ \\
$\mathrm{pH}$ & $7,5-8.5$ \\
\hline
\end{tabular}

Table 6 Chemical test results (Soluble ions) of the road soil

\begin{tabular}{llllllllll}
\hline Soluble Ions & & & & & & & \\
\hline Soil & Salt $\%$ & $\mathrm{C}++$ & $\mathrm{Mg}++$ & $\mathrm{Na}+$ & $\mathrm{K}+$ & me CO3 - & me HCO3 - & $\mathrm{dm}-3 \mathrm{HCO}-$ & $\mathrm{SO}-4$ \\
\hline Al Hosh & 79 & 1.05 & 0.6 & 16.03 & 0.04 & 0 & 3.05 & 2.83 & 3.21 \\
\hline
\end{tabular}

Table 7 Chemical test results $(\mathrm{pH})$

\begin{tabular}{|c|c|c|c|c|c|c|c|c|}
\hline \multirow{3}{*}{ Soil } & \multirow{3}{*}{ SAR } & \multirow{2}{*}{ pH } & & & & & \multicolumn{2}{|c|}{ Extractable Actions Me 100g-1 Soil } \\
\hline & & & & & & & Na & $\mathbf{K}$ \\
\hline & & EC Ms cm-1 & $0.01 \mathrm{M} \mathrm{CaC12}$ & Paste & \multicolumn{2}{|l|}{ H2O } & $\mathrm{H} 2 \mathrm{O}$ & \\
\hline & & & 01:02.5 & & 01:02.5 & 1:05 & & \\
\hline Al Hosh & 17.65 & 1.14 & 7.89 & 8.44 & 9.1 & 9.25 & 10.46 & 0.95 \\
\hline
\end{tabular}

The local grass and small bushes around the road are the grass belonged to Poaceae family it called in Sudan (Nigella) Cynodon Dactylon, transvaalin sis, and some kinds of Cyperuses as Cyperus focus and Cyperus Capitates (Figure 12). And the small bushes call in
English (Mesquite) scientific name is (Proscopis) and it covers a wide area in the Gezira state, which has the ability to stabilize the soil any it can grow in the areas have a lack of rain as shown below: 


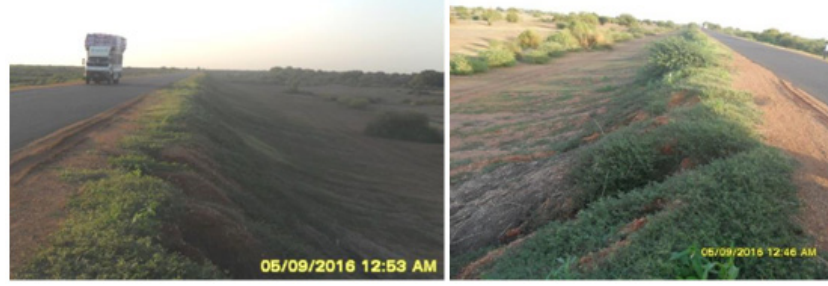

Figure I 2 Existing natural local grass and (Mesquite) plant covered part of National Road side slope.

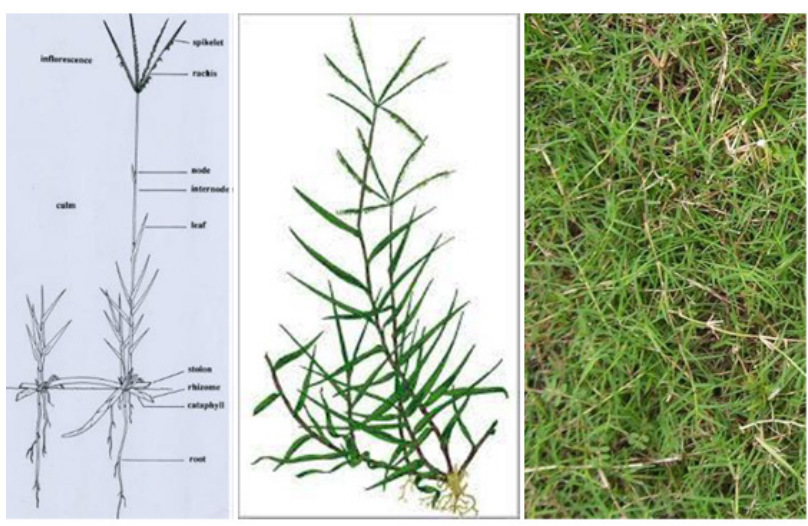

Figure I3 Cynodon Dactylon.

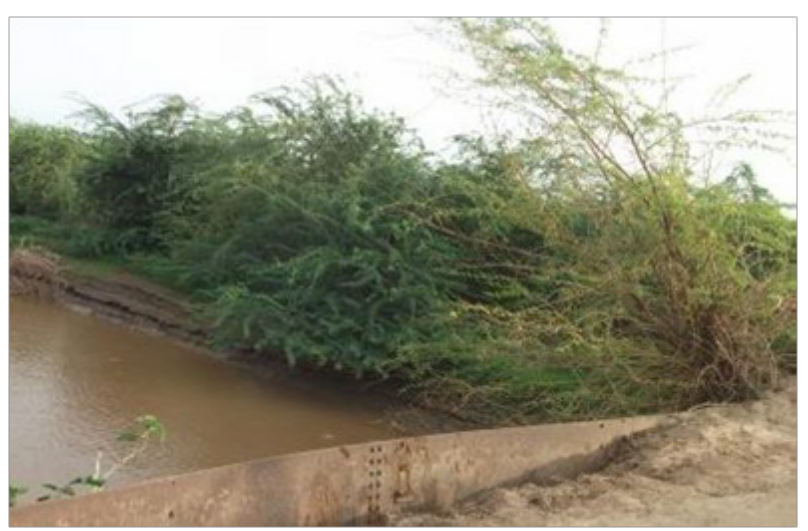

Figure I 4 Prosopis (mesquite) in black rain area, and beside irrigation channel in Gezira scheme.

\section{Discussion}

\section{Analysis of the possibility and necessary by applying such these eco-protection technology in Sudan}

Based on all the background introduced and data as (environment factor, a field survey of the slope, soil experiments in labs, exist plants surveying). The study found the possibility of using of slope Ecoprotection for the Roadway, it is important and necessary to control slope erosion. That proved by existing plants and grass can be an important and the main factor of applying Eco-Protection Technology in Sudan (Gezira Stat). And can design, vegetation spices percentage depending on the soil fertility and local plants growing surrounding the site area of the roadway.

\section{Plants, grass, and weeds that can be used in ecological protection}

Depending on site studies, serving measures, soil tests, meteorological information, the results of all tests and the exciting plants and grass in the Road, this research study can apply Biotechnological slope protection using re- vegetation method to restore the eroded slope of the road. There is a possibility of having different grasses and plants for using in Eco-protect the road, during the discussion with Dr. Awad Allah Belal, said lecturer in the college of agricultural sciences in Gezira University. The study can explain the idea of using grass and plants in Eco- protection for the road, he suggests using from Poaceae family the type called (Cynodon Dactylon).${ }^{14}$ Because of its properties as it can fit for cultivation in the Gezira state, it's rooted deep if we compared with other types of Poaceae families. The most important properties of its roots to hold the soil surrounding the root zone, the root depth ranges between17$25 \mathrm{~cm}$ deep.

\section{Cynodon dactylon}

The original home of the Cynodon Dactylon is tropical regions of Africa, in the zone of $p$ the main weeds in crops of (Aldrua, sugar cane and many other cops), and in many of countries have registered Cynodon Dactylon as a problem in 40 agricultural crop land. In spite of this, some trains are very useful these plants graze cattle. Some of it can use to prevent soil erosion, and others give a wonderful promoter of sports as hiking of golf. ${ }^{15}$ So it is better to use Cynodon Dactylon and mixing with other plants and grasses in the Eco-protection of the Road from erosion. It is adopted with a broad range of soil types from sandy to heavy clay, although it would preferred modules and heavy soil moist and rain. Also, it grows in alkaline soil and acidic alike and can withstand flooding and drought conditions. But it also grows in arid areas along waterways and in areas water rights. In Srilanka as an example, it cultivated on the edge of ponds to help bind the soil around it. And near Roosevelt Dam, in Arizona at the USA, it stands at the high floods, water and it can stand like that for a whole year. Soil testing to determine the chemical components to know fertility of the soil on site, so it's helpful to know the types of grass family and plants that can use in future to slope ecological protection in the high embankment of the road. This chemical soil test did in the Gezira University-college of agricultural sciences and water resources (Figure 13). From collaborating with teachers from Gezira University we discussed the possibilities of using vegetation (plants and grass family) according to soil fertility, knowing the existing natural plant grasses in the site, determining the suitable Poaceae as Cynodon Dactylon is also known as Vfastella. ${ }^{15}$

\section{Mesquite}

Prosopis (mesquite) is a tropical and subtropical tree and shrub, mainly found in the arid and semi-arid regions of the world. ${ }^{16}$ The introduction of Mesquite into the Sudan Mesquite was introduced into the Sudan in 1917 by the government botanist E. Massey. The purpose was to find exotic fast growing tree species resistant to drought and grazing, have value for the conservation of ecological balance, the source of fuelwood and fodder and other economic values (Figure 14). The first plants were planted in a small agricultural research farm on the outskirts of Khartoum. Field trials were made in 1928 outside the city where the results were not very promising, but in the same trial Prosopis proved successful on the sands under rainfall not exceeding $150 \mathrm{~mm}$ per annum. ${ }^{9}$ Mesquite contributes to environmental stability 
through stabilization of sand dunes, hedging, windbreaks, shelterbelts around villages and agricultural schemes. Mesquite as Prosopis can use in the areas with shortages of rainfall, Mesquite s an integral part of the desert ecosystem in both North and South America. ${ }^{17}$ Also, theuy are many studies of evaluating mesquite and its adaptation to the environment, according to global climate changes, and states the effects of Mesquite in agricultural areas in Sudan. ${ }^{18}$ The study expects to use Mesquite plants because of its ability to stabilize soil and it can plant in the place of lack rainfall. Even Mesquite trees can drought tolerance and grow well in full to reflected sun as well as in partial shade. ${ }^{19}$ This study can continue by doing other extension researchers focusing on the same purpose of the paper research area, and also special studies of design seeds and plant species (vegetation on the slope covering) for using in highway embankment slope protection as Biotechnology slope protection. ${ }^{20-22}$

\section{Conclusion}

Based on the experimental analysis conducted above and the research established for ecological slope vegetation protection, it can be concluded that:

A. According to the Road Slope soil experiments (Geotechnical and Chemical) Results, using Eco- Protection as vegetation side slope can be possibly used in control slope failure along the Road.

B. The example of successful vegetation slope is that part of the slope which covered by the existing vegetation (local grass community) and shows less slope soil erosion by rainfall intensity during the autumn season.

C. Make expanding research papers on the upper-mentioned results, and open the eco-protection studies zone for other researchers for digging and adopting the ecological slope protection in Sudan Highway construction.

D. Vegetation slopes and covering lands have many benefits for improving the general climate and increasing the rainfall intensity situation, and this is very important methods to keep and land from transform to be desert land.

\section{Acknowledgments}

This research was supported by the National Natural Science Foundation of China: "Study on nutrient circulation around rock face-substrate-vegetation in vegetation-growing concrete ecological protection engineering" Grant No (51678384) and Natural Science Foundation of Hubei Province: 边坡生态防护持续性限制克 服的矢键技术研究 (2016CFA085). The authors would like to acknowledge Stacy L. Hutchinson, Ph.D., Associate, Professor College of Engineering, Kansas State University, Biological and Agricultural Engineering Department., (USA). .Prof. Adam Ibrahim, Prof. Muawia El-Bedawi, Dr. Ali Babikr, Dr. Mahmoud Mohammed, Eng. Osman Altayeb, Eng. Altayeb Albthany and Tech. Haram Adam for their indispensable cooperation (Sudan), Dr. Zhao (China CTGU).

\section{Conflict of interest}

Author declares that there is no conflict of interest.

\section{References}

1. Elizabeth Seutloali K, Reinhard Beckedahl H. A Review Of RoadRelated Soil Erosion: An Assessment of Causes, Evaluation Techniques and Available Control Measures. Earth Sciences Research Journal. 2015;19(1):73-80.
2. Marian M, Connie M, Roger G, et al. Erosion Control for Highway Applications. Final Report TR-464, USA; 2002.

3. Scarborough George JA, Filz James K Mitchell, Brandon TL. Erosion Protection For Soil Slopes Along Virginias Highways. Final Contract Report, Virginia, USA; 2000.

4. Gaitskell A. The Gezira Scheme. Journal of the Royal Society of Arts. 1955;104(4966):67-86.

5. Charlie WA, Mohamed AO, Elfatih MA. Construction on Expansive Soils In Sudan. ASCE. 1984;110(3):1-3.

6. (SMA). Sudan Seasonal Monitor- Evaluation Report-Season 2012 Government Team, Sharma, Sudan Meteorological Authority, India; 2002. p. 29-30.

7. Braja MD. Geotechnical Engineering Handbook. USA: J Ross Publishing; 2011. p. 499.

8. American Society for Testing Materials (ASTM 1992ao) and the US. Army Department (DOA 1970), USA.

9. Ramos Scharron CE, Macdonald LH. Run off and suspended sediment yields from unpaved road segment. Hydrological Processes. 2007;21(1):35-50

10. Bochet E, Garcia Fayos P, Tormo J. How can we control erosion of road slopes in semiarid Mediterranean areas Soil improvement and native plant establishment. Land Degradation \& Development. 2010;21(2):110-121.

11. Jankauskas B, Jankauskiene G, Fullen MA, et al. Utilizing palm-leaf Geotextiles to control soil erosion on roadside slopes in Lithuania. Agricultural Sciences. 2008;15(3):22-28.

12. Andrew TL. Bio-Technology for Slope Protection and Erosion Control. $A$ Conference on Watershed Stewardship. 1998. p. 27-30.

13. Hamad ME. Thesis Phosphorus with some Calcareous from the Sudan University of Newcastle upon Tyne, UK; 1989:1-13.

14. Chippindall, Crook AO. Grass of southern Africa. Collins, USA; 1976.

15. Gibbs Russell GE, Watson L, Koekemoer, et al. Grasses of southern Africa. Memoirs of the Botanical Survey of South Africa No. 58. 1991.

16. Abdel Magid TD, Nour Abdalla El, Siddig EI, et al. Mesquite in Sudan: A Boon or Bane for Drylands? Its Socioeconomic and Management Aspects in Kassala State, Sudan. Journal of Forest Products \& Industries. 2014;3(4):183-190.

17. Hoshino B, Yonemori M, Manayeva K, et al. Remote Sensing Methods For The Evaluation Of The Mesquite Tree (Prosopis Juliflora) Environmental Adaptation To Semi-Arid Africa. Japan; 2011. p. 1-5.

18. Ursula KS, Kelly JJ. Mesquite and Palo Verde Trees in the Urban Landscape. Arizona Cooperative E Tension. 2014.

19. Gray DH, Leiser AT. Biotechnical slope protection and erosion control. Van Nostrand Reinhold Company, USA; 1982. p. 271.

20. Bashan Y, Salazar BG, Moreno M, et al. Restoration of eroded soil in the Sonoran Desert with native leguminous trees using plant growthpromoting microorganisms and limited amounts of compost and water. $J$ Environ Manage. 2012;102:26-36.

21. Jackson JK. The introduction of exotic trees, Prosopis juliflora (Swantz) DC Sudan. 1960;1:14-30.

22. DeLoach CJ. Conflicts of Interest Over Benefits and Undesirable Aspects Of Mesquite (Prosopis spp.) in the United States as Related to Biological Control. Canada; 1984. p. 19-26. 